\title{
THE FRESHWATER FISHES OF THE MIDDLE AND LOWER ORANGE RIVER
}

\author{
P. H. SKELTON
}

Albany Museum

Grahamstown

6140

\section{J. A. CAMBRAY}

Cape Department of Nature and Environmental Conservation

Rolfontein Nature Conservation Station

P.O. Box 23

Vanderkloof

8771

\begin{abstract}
The occurrence and distribution of freshwater fishes of the middle and lower Orange River in the Republic of South Africa is presented, based on a survey conducted in September 1980. Particular attention is paid to the Augrabies Falls region including the Augrabies Falls National Park. Comments on the distribution and conservation status of the fishes are given.
\end{abstract}

\section{Introduction}

Fishes of the Orange River system were among the very first to be described from southern African freshwaters (Burchell 1822; Smith 1841). The freshwater fish fauna of this system is now well known (Barnard 1943; Jubb \& Farquharson 1965; Jubb $1965,1967)$. In spite of this, the details of distribution of several species within the system are not well recorded. This is especially true of the middle and lower reaches of the river, downstream from the confluence of the Vaal and Orange Rivers.

Available records have indicated that the Augrabies Falls $\left(28^{\circ} 36^{\prime} \mathrm{S}, 20^{\circ}\right.$ $20^{\prime} \mathrm{E}$ ) form a barrier to freshwater fishes. At least two species (Barbus hospes, Neobola brevianalis) are restricted to the river below this waterfall (Jubb \& Farquharson 1965; Jubb 1967), whilst certain species are recorded only from above the falls. The latter group includes the rock catlet Gephyroglanis sclateri and the otherwise widespread and common gillieminkie Barbus anoplus. An investigation of the fish fauna of the Augrabies Falls region was obviously important in view of the distribution barrier there and the fact that this region is a declared national park.

An investigation of the conservation status of the fishes of the lower Orange was also required, especially in the case of the minnow Barbus hospes which was placed on the endangered list by Skelton (1977). Furthermore there has been no monitor- 
ing of the downstream effects on the fish fauna after the construction of several large impoundments and this survey intended therefore to at least place on record the present status of fish species in the middle and lower reaches of the Orange River.

The survey was made between 16-25 September 1980 and included:

1) The middle Orange River from immediately above the Vaal-Orange confluence to several small tributaries immediately above the Augrabies Falls; 2) The Augrabies Falls National Park (AFNP) and vicinity; 3 ) The lower Orange River as far downstream as Vioolsdrift (Figs 1 \& 2).

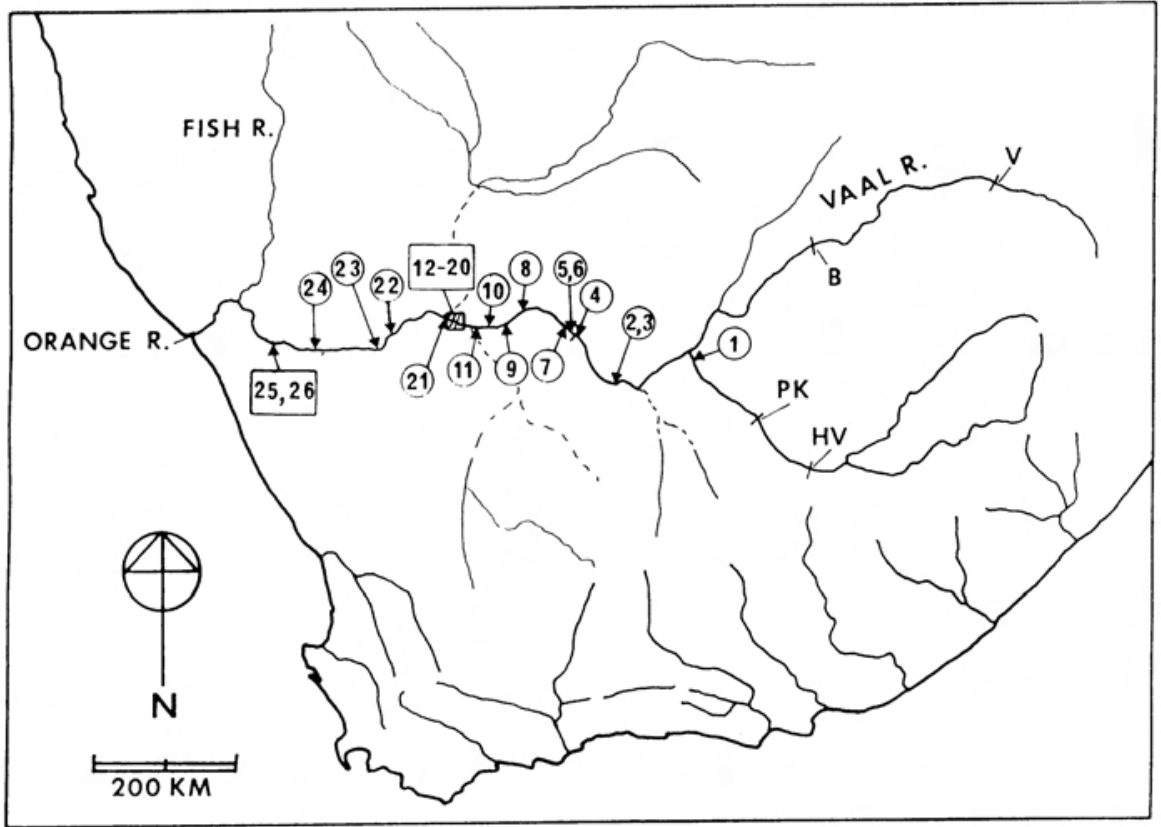

Fig. 1. The Orange River in southern Africa showing major impoundments and station localities of September 1980 fish survey as recorded in text. Abbreviations: B - Bloemfhof Dam; HV - Hendrik Verwoerd Dam; PK - P K le Roux Dam; V - Vaal Dam. Sites 12-20 detailed in Fig. 2.

\section{Methods}

Fishes were collected using a variety of methods which depended on the habitat type. These methods included a $140 \mathrm{~m}$ fleet of gill nets $(40,50,60,85,93,118$ and $150 \mathrm{~mm}$ stretched mesh); seine nets of four kinds ( a $25 \mathrm{~m} 32 \mathrm{~mm}$ mesh; 10 and $15 \mathrm{~m}$ anchovy mesh bagged seines; $3 \mathrm{~m}$ mosquito netting seine); hand scoop net; electric shocker (1,6kva 280 volts, hand held electrodes); Pronox piscicide; baited longline; handlines and conventional rod and line. Specimens were preserved in $10 \%$ formalin. Surplus catches were returned to the water alive. Certain larger specimens caught in gill nets and long lines were weighed, measured, sexed but not preserved. Retained specimens are housed in the Albany Museum, Grahamstown. 


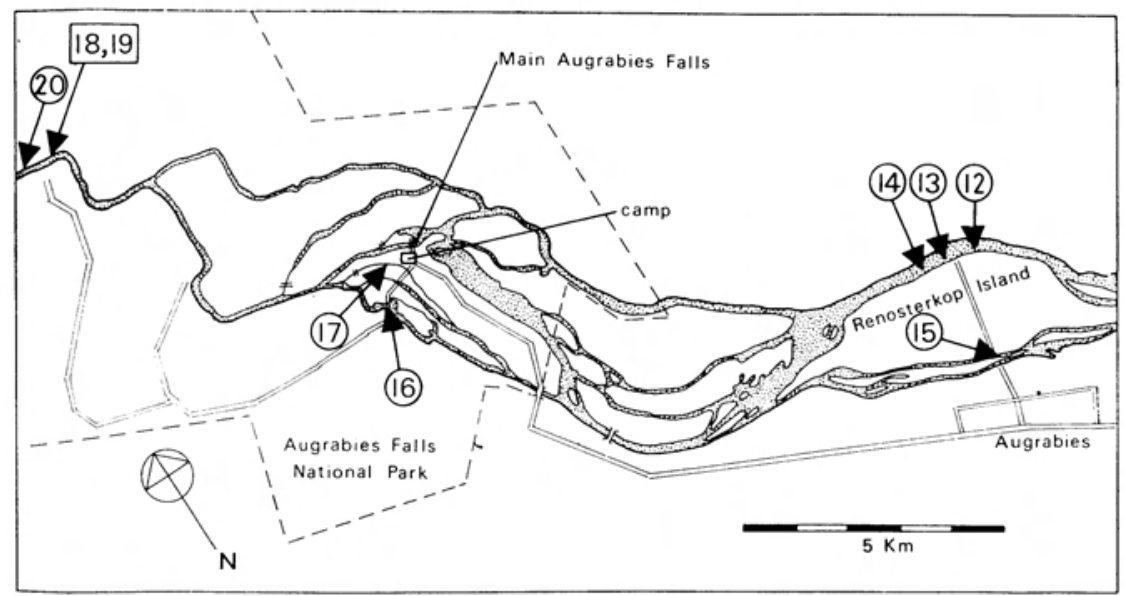

Fig. 2. The Augrabies Falls region of the Orange River showing collecting stations of September 1980 fish survey as recorded in text. Dashed line marks Augrabies Falls National Park boundary.

\section{Collecting Sites and Habitats}

Collecting localities are recorded on figures $1 \& 2$. Middle Orange River stations were situated mainly where bridges cross the river. There was only one reasonably accessible site below Augrabies Falls within the gorge (Echo Corner) and a variety of methods was used to sample the fish population at this site. Proceeding downstream collections were taken by electrofishing and seining at Blouputs, Onseepkans, Pella Drift, Goodhouse and Vioolsdrift. Descriptions of the habitat at each collecting site (Station) is given below. Station numbers refer to localities on Figs $1 \& 2$.

\section{Middle Orange River}

Station 1: Orange River at F.A. Loots Bridge $\left(29^{\circ} 09^{\prime} 41^{\prime \prime} \mathrm{S}\right.$; $23^{\circ} 41^{\prime} 48^{\prime \prime} \mathrm{E}$ ). The area downstream of the bridge is very rocky with alternating sandy patches and sparse vegetation. Upstream there is a small weir, with several mud banks behind it. Riparian trees and several small sedge beds characterize the site. The river was flowing strongly and approximately $175 \mathrm{~m}$ wide at this point. One of the shallow gently sloping silty banks behind the weir was seined with the 15 $\mathrm{m}$ anchovy seine.

Station 2: Orange River at Prieska Bridge $\left(29^{\circ} 39^{\prime} 38^{\prime \prime} \mathrm{S} ; 22^{\circ} 44^{\prime} 41^{\prime \prime} \mathrm{E}\right)$. Seined an isolated pool beside the main channel of the river, surrounded by dense stands of reeds (Phragmites australis) with some riparian vegetation. The pool had a sandy-silty substrate, a maximum depth of $1,5 \mathrm{~m}$ and maximum width of $20 \mathrm{~m}$. The pool is probably connected to the main stream by seepage at low levels and is part of the river during peak flow periods.

Station 3: Orange River at Prieska Bridge $\left(29^{\circ} 39^{\prime} 38^{\prime \prime} \mathrm{S} ; 22^{\circ} 44^{\prime} 41^{\prime \prime} \mathrm{E}\right)$. This section of the river is characterized by both steep and shallow sloping sandy 
banks with scattered reed beds. Low water level exposed large open sandy areas across half of the riverbed. P. australis beds were isolated from the present waters edge. The sampling site had a sandy substrate with scattered boulders. Water temperature was $17,6^{\circ} \mathrm{C}(30 \mathrm{~cm})$ at $12 \mathrm{~h} 30$. The $15 \mathrm{~m}$ anchovy seine was used over a distance of $50 \mathrm{~m}$.

Station 4: Orange River at Boegoeberg Dam $\left(29^{\circ} 02^{\prime} 40^{\prime \prime} \mathrm{S}\right.$; $\left.22^{\circ} 12^{\prime} 11^{\prime \prime} \mathrm{E}\right)$. A site near the Dept. of Water Affairs camping grounds was seined. This area has a sandy substrate with $P$. australis beds extending into the impoundment. The water was turbid, with a temperature of $19,2^{\circ} \mathrm{C}(30 \mathrm{~cm})$ at $18 \mathrm{~h} 00$. There was a strong onshore wind at sampling time. Two $30 \mathrm{~m}$ pulls of the $15 \mathrm{~m}$ anchovy seine were completed at a depth of up to $1 \mathrm{~m}$ along an open sandy beach.

Station 5: Orange River, $0,75 \mathrm{~km}$ below Boegoeberg Dam $\left(29^{\circ} 02^{\prime} 27^{\prime \prime} \mathrm{S}\right.$; $22^{\circ} 11^{\prime} 49^{\prime \prime} \mathrm{E}$ ). Immediately below the Boegoeberg Dam wall the river is very rocky and full of rapids inhibiting seining. A quiet side channel was sampled where the banks were covered with $P$. australis and overhanging trees. The substrate was rocky and covered with fine silt ( $\pm 5 \mathrm{~cm}$ deep) and the water temperature was $18,3^{\circ} \mathrm{C}(30 \mathrm{~cm})$ at $09 \mathrm{~h} 00$. An area of $30 \mathrm{~m}^{2}$ with an average depth of $0,5 \mathrm{~m}$ was rotenoned.

Station 6: Orange River $1 \mathrm{~km}$ below Boegoeberg Dam wall $\left(29^{\circ} 02^{\prime} 17^{\prime \prime} \mathrm{S}\right.$; $22^{\circ} 11^{\prime} 31^{\prime \prime} \mathrm{E}$ ). This station was located in a $25 \mathrm{~m}$ wide side channel similar to the previous one except for a sandy bank on one side which enabled use of the $15 \mathrm{~m}$ anchovy seine. The substrate was scattered silt covered rocks with emergent vegetation. The site was subject to water level fluctuations from the varying outflow of Boegoeberg Dam. Water temperature was $18,5^{\circ} \mathrm{C}(30 \mathrm{~cm})$ at $09 \mathrm{~h} 00$.

Station 7: Orange River at Groblershoop Bridge $\left(28^{\circ} 53^{\prime} 39^{\prime \prime} \mathrm{S} ; 22^{\circ}\right.$ $\left.00^{\prime} 00^{\prime \prime} \mathrm{E}\right)$. A strong flow in the river at the time limited the sampling at this site. The river was over $150 \mathrm{~m}$ wide with fairly open sandy shores, scattered $P$. australis stretches and some riparian vegetation. Rocky rapid areas were scarce. Water temperature was $20,4^{\circ} \mathrm{C}(30 \mathrm{~cm})$ at $16 \mathrm{~h} 00$. A sandy stretch between several reedy areas was seined to a depth of $1 \mathrm{~m}$ with a $15 \mathrm{~m}$ anchovy mesh net. Three seines of 20, 20 and $30 \mathrm{~m}$ were completed.

Station 8: Orange River at Upington Bridge ( $\left.28^{\circ} 27^{\prime} 46^{\prime \prime} \mathrm{S} ; 21^{\circ} 15^{\prime} 51^{\prime \prime} \mathrm{E}\right)$. This site was characterized by a sandy substrate and dense $P$. australis reed beds along sandy banks and on several small islands. Water temperature was $20,2^{\circ} \mathrm{C}$ $(30 \mathrm{~cm})$ at $13 \mathrm{~h} 30$. A slow-flowing side channel was seined to a depth of $1 \mathrm{~m}$ over a distance of $35 \mathrm{~m}$ with the $15 \mathrm{~m}$ anchovy net.

Station 9: Orange River at Manie Conradie Bridge, Kanoneiland $\left(28^{\circ}\right.$ $38^{\prime} 7^{\prime \prime} \mathrm{S} ; 21^{\circ} 5^{\prime} 30^{\prime \prime} \mathrm{E}$ ). In this area the river braids to form large cultivated islands. The banks were lined with Typha sp., $P$. australis and various trees. Several weirs in the river create quiet backwater areas suitable for seining. The substrate was coarse sand with scattered rocky outcrops. Water temperature was $20^{\circ} \mathrm{C}$ $(30 \mathrm{~cm})$ at $11 \mathrm{~h} 30$ in a flowing section. Three seine hauls with the $15 \mathrm{~m}$ anchovy net were completed for a total distance of $55 \mathrm{~m}$, in depths of less than $1 \mathrm{~m}$.

Station 10: Orange River at Keimoes Bridge $\left(28^{\circ} 43^{\prime} 48^{\prime \prime} \mathrm{S} ; 20^{\circ}\right.$ $\left.59^{\prime} 11^{\prime \prime} \mathrm{E}\right)$. The river was approximately $150 \mathrm{~m}$ wide over a rocky area, with abun- 
dant rapids and some large islands covered with $P$. australis and trees. Typha sp. and $P$. australis beds occurred along the shoreline. Water temperature was $19,8^{\circ} \mathrm{C}(30 \mathrm{~cm})$ at $10 \mathrm{~h} 00$. A seine haul restricted by the current of approx. $1 \mathrm{~m} \mathrm{sec}^{-1}$, was made through the reedbeds over a sandy substrate. A hand scoopnet was also used in the reed beds with limited success.

Station 11: Orange River at Kakamas Bridge $\left(28^{\circ} 45^{\prime} 17^{\prime \prime} \mathrm{S} ; 20^{\circ}\right.$ $37^{\prime} 23^{\prime \prime}$ E). Here there were dense $P$. australis beds along the banks and on several small islands. The river is approximately $200 \mathrm{~m}$ wide at this point. Water temperature was $19,6^{\circ} \mathrm{C}(30 \mathrm{~cm})$ at $08 \mathrm{~h} 30$. Due to a strong current only a restricted seine haul over a sandy and rocky substrate was made.

Station 12: Orange River mainstream at Renosterkop Island, Augrabies $\left(28^{\circ}\right.$ $\left.38^{\prime} 32^{\prime \prime} \mathrm{S} ; 20^{\circ} 25^{\prime} 44^{\prime \prime} \mathrm{E}\right)$. Seine netted shallow gently sloping $(0,5-2 \mathrm{~m})$ left hand bank on the open water side of broad $P$. australis beds ( $20 \mathrm{~m}$ wide). Mainstream 75 $100 \mathrm{~m}$ wide with sandy and partly silty substrate. $P$. australis beds along both banks.

Station 13: Orange River mainstream at Renosterkop Island, Augrabies $\left(28^{\circ}\right.$ $\left.38^{\prime} 32^{\prime \prime} \mathrm{S} ; 20^{\circ} 25^{\prime} 40^{\prime \prime} \mathrm{E}\right)$. Netted with large seine an open channel with bedrocksand substrate and $P$. australis banks.

Station 14: Orange River mainstream at Renosterkop Island, Augrabies $\left(28^{\circ}\right.$ $\left.38^{\prime} 32^{\prime \prime} \mathrm{S} ; 20^{\circ} 25^{\prime} 40^{\prime \prime} \mathrm{E}\right)$. Electrofished rocky-rapid stretch of river with $P$. australis banks and riparian tree vegetation. Substrate smooth, irregular bed rocks, banks muddy, sandy channels between rocks.

Station 15: Braided channel of Orange River at Augrabies town $\left(28^{\circ}\right.$ $\left.39^{\prime} 42^{\prime \prime} \mathrm{S} ; 20^{\circ} 25^{\prime} 31^{\prime \prime} \mathrm{E}\right)$. This muddy bedded channel was densely occupied by $P$. australis reeds and strewn with fallen logs. The floating aquatic fern, Azolla sp., occurred between the reeds. The channel was $5-10 \mathrm{~m}$ wide and $0-2 \mathrm{~m}$ deep. Water flow was not detected. A relatively open pool was worked with the $10 \mathrm{~m}$ anchovy seine.

Station 16: Braided channel above the Augrabies Falls at drift on west road from the tourist centre in the AFNP $\left(28^{\circ} 35^{\prime} 45^{\prime \prime} \mathrm{S} ; 20^{\circ} 20^{\prime} 16^{\prime \prime} \mathrm{E}\right)$. The site consisted of a slow flowing, clear water stream with bedrock, and a boulder strewn and sandy substrate. The pools varied from $0-3 \mathrm{~m}$ wide and were usually less than $1 \mathrm{~m}$ deep, but occasionally 1-2 m deep. Marginal vegetation (Cyperaceae) found in .broken patches as well as emergent aquatic vegetation (Gomphostigma virgatum) and algal mats (Spirogira sp.). Water temperature was $17^{\circ} \mathrm{C}$ at $10 \mathrm{~h} 00$. The site was worked using a $10 \mathrm{~m}$ anchovy seine net and a $3 \mathrm{~m}$ mosquito seine.

Station 17: Braided channel of Orange River above Augrabies Falls behind the Caravan Park $\left(28^{\circ} 15^{\prime} 34^{\prime \prime} \mathrm{S} ; 20^{\circ} 20^{\prime} 08^{\prime \prime} \mathrm{E}\right)$. The stream was flowing slowly with a rocky and sandy substrate and clear water and considerable riparian shade. The stream was from 1-3 m wide and between 0-2 $\mathrm{m}$ deep in the larger pools. Small $P$. australis and Cyperaceae beds occurred and algal mats (Spirogira sp.) were scattered throughout.

\section{Lower Orange River}

Station 18: Cut off pool from main channel at "Echo Corner" AFNP $\left(28^{\circ} 32^{\prime} 44^{\prime \prime} \mathrm{S} ; 20^{\circ} 17^{\prime} 15^{\prime \prime} \mathrm{E}\right)$. Seine netted about $20 \mathrm{~m}$ of this $70-100 \mathrm{~m}$ 
long pool. Rotenoned approximately $80 \mathrm{~m}^{2}$. Pool consisted of sandy and light silt bottom with minimal marginal vegetation (small $P$. australis bed $2 \mathrm{~m}^{2}$ ) and water grass patches, and large boulders and rocks scattered throughout. Pool depth 0-2 m; width $10-20 \mathrm{~m}$. Water turbid, temperature $19,4^{\circ} \mathrm{C}$ at $11 \mathrm{~h} 00$.

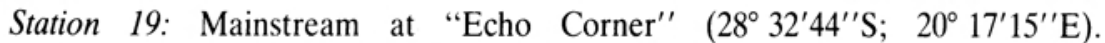
The river was between $50-100 \mathrm{~m}$ wide with a sandy-silt bottom and shallow sloping bed. Depth not recorded but at least several metres. Banks sandy-rocky with small Cyperaceae patches. Collecting methods included mosquito, anchovy and large seine nets, gill nets, long line and handlines.

Station 20: Mainstream, right bank, $200 \mathrm{~m}$ downstream from "Echo Corner" AFNP $\left(28^{\circ} 32^{\prime} 41^{\prime \prime} \mathrm{S} ; 20^{\circ} 17^{\prime} 05^{\prime \prime} \mathrm{E}\right)$. Electrofished between large scattered boulders and rocks with silt-sand bottomed channels and a small Cyperaceae bed. Water depth up to $1 \mathrm{~m}$.

Station 21: Orange River at Blouputs, below AFNP $\left(28^{\circ} 31^{\prime} 00^{\prime \prime} \mathrm{S}\right.$; $\left.20^{\circ} 12^{\prime} 30^{\prime \prime} \mathrm{E}\right)$. Electrofished rocky rapid stretch of river separating open sandy stretches. River estimated at between $50-70 \mathrm{~m}$ wide, worked in depths from $0,2-1 \mathrm{~m}$. Current speed estimated at approximately $0,8 \mathrm{~m} \mathrm{sec}$ (surface) and $^{-1}$ $0,7 \mathrm{~m} \mathrm{sec}^{-1}$ subsurface. Water temperature $19^{\circ} \mathrm{C}$ at $12 \mathrm{~h} 00$. Banks rocky, with patches of Cyperaceae, Gomphostigma virgatum and P. australis.

Station 22: Orange River at Onseepkans $\left(28^{\circ} 44^{\prime} 00^{\prime \prime} \mathrm{S} ; 19^{\circ} 18^{\prime} 15^{\prime \prime} \mathrm{E}\right)$. The river braids into channels to form small islands. The channels vary from 5-15 $\mathrm{m}$ in width and depth $0,5-2 \mathrm{~m}$. Substrate is sandy-gravel with rock rapid stretches. Banks and island shores have $P$. australis beds and beds of Cyperaceae. River bed approximately $0,5 \mathrm{~km}$ wide, although only $100-200 \mathrm{~m}$ of the bed was filled with flowing water at the time of sampling. Temperature recorded in channel $19^{\circ} \mathrm{C}$ at $09 \mathrm{~h} 00$, surface current varied from $0,7-1 \mathrm{~m} \mathrm{sec}^{-1}$ (subsurface current 0,6-0,8 $\left.\mathrm{sec}^{-1}\right)$. Electrofished, seine netted and used rod and line.

Station 23: Orange River at Pelladrift $\left(28^{\circ} 57^{\prime} 29^{\prime \prime} \mathrm{S} ; 1^{\circ} 10^{\prime} 27^{\prime \prime} \mathrm{E}\right)$. Electrofished along silted loose rocky and sandy shore. Water depth 0,2-1 m (mainly $0,5 \mathrm{~m})$. No marginal vegetation at this point.

Station 24: Orange River at Goodhouse $\left(28^{\circ} 53^{\prime} 50^{\prime \prime} \mathrm{S} ; 18^{\circ} 14^{\prime} 18^{\prime \prime} \mathrm{E}\right)$. Seined with $10 \mathrm{~m}$ anchovy seine off sandbar and shallow inlet on right hand shore. River bed sandy and shallow sloping approximately $100-150 \mathrm{~m}$ wide. Banks have riparian forest and broken patches of $P$. australis and Cyperaceae beds. Small water grass patches encountered in seined area.

Station 25: Orange River below weir near Vioolsdrift $\left(28^{\circ} 45^{\prime} 00^{\prime \prime} \mathrm{S}\right.$; $\left.17^{\circ} 43^{\prime} 00^{\prime \prime} \mathrm{E}\right)$. Electrofished rocky rapids and shore with grassy inlets. Rocks covered with fine silt in sheltered places. Water temperature $19,5^{\circ} \mathrm{C}$ at $10 \mathrm{~h} 00$.

Station 26: Orange River below weir near Vioolsdrift $\left(28^{\circ} 45^{\prime} 00^{\prime \prime} \mathrm{S}\right.$; $\left.17^{\circ} 43^{\prime} 00^{\prime \prime} \mathrm{E}\right)$ Seined a shallow sloping sandy bottomed open river stretch below station 25. P. australis beds along both shores and small patches of water grass (Zanichella palustris) off shore in seined area. River approximately $100 \mathrm{~m}$ wide, and from 0-1,5 m deep over seined area. 
A summary of the fish species collected at each site is given in Table 1 . The table provides a general indication of the distribution of the species, but as certain stations involved selective collecting from particular habitats, a better understanding of species distribution is given in the annotated list below.

Barbus anoplus: Although generally widespread and common in South Africa (Jubb 1967) the distribution of this minnow in the Orange River is puzzling. Albany Museum records indicate that it is common in southern tributaries of the Orange within the Cape Province, as well as in the Orange Free State and Transvaal catchment regions of the Vaal-Orange system. It is common in the marginal areas of both the Hendrik Verwoerd and P. K. le Roux impoundments (Cambray, Hahndiek \& Hahndiek 1978; Cambray \& Hahndiek 1980). The survey team collected only two specimens from a pool at Prieska and no records of the species are known from the system below this point.

Barbus holubi: The smallmouth yellowfish is widely distributed throughout the Orange River System (Jubb 1967). The species was encountered at most stations of the survey although nowhere in great numbers. No larvae or specimens of a size which would indicate that breeding had occurred since last winter were found. The species was most abundant in flowing water (even in rapids on occasions) with a sandy-gravel substrate. Specimens were caught on rod and line in the strong-current channels above the main falls. Inspection of the gut contents of several individuals at Echo Corner (AFNP) indicated that the preferred food item was the pelecypod mollusc Corbicula africana. The above observations support the findings of Mulder (1973a) with regard to the habitat preference and feeding of B. holubi. Smaller specimens were silvery in colour with distinctly salmon-orange fins (most notable in the anal fin). Larger specimens assumed a golden hue with the fins frequently retaining the salmon-orange. The largest specimen caught had a standard length of $43 \mathrm{~cm}$ and a mass of $1975 \mathrm{gm}$.

Barbus hospes: The Namaqua barb is an extremely specialized small Barbus species known only from the Orange River below Augrabies Falls (Barnard 1943, Jubb 1967). Skelton (1977) included this species in the threatened category of the South African Red Data Book - Fishes, and one of our tasks was to evaluate this listing. Throughout the survey we encountered the species only in small numbers. On morphological considerations, $B$. hospes appears to be a strong swimming, flowing-water form adapted to substrate feeding habits. In general, our observations corroborated this view as we most often found this species in the open water of the mainstream. Individuals were also electrofished from the rapids. The species did not appear to have bred at the time of the survey although adult specimens in ripe condition were collected. The survey indicated that the species is not common and should be retained on the red data list as rare in view of its morphological specializations and restricted distribution.

Barbus kimberleyensis: There are no previous museum records of the largemouth yellowfish from below the Augrabies Falls, although the species was in fact known from that stretch (Skelton, personal observations, 1973). As reported elsewhere in the Orange-Vaal River system (Marshall 1972; Van Schoor 1972; Mulder 1973a), B. 


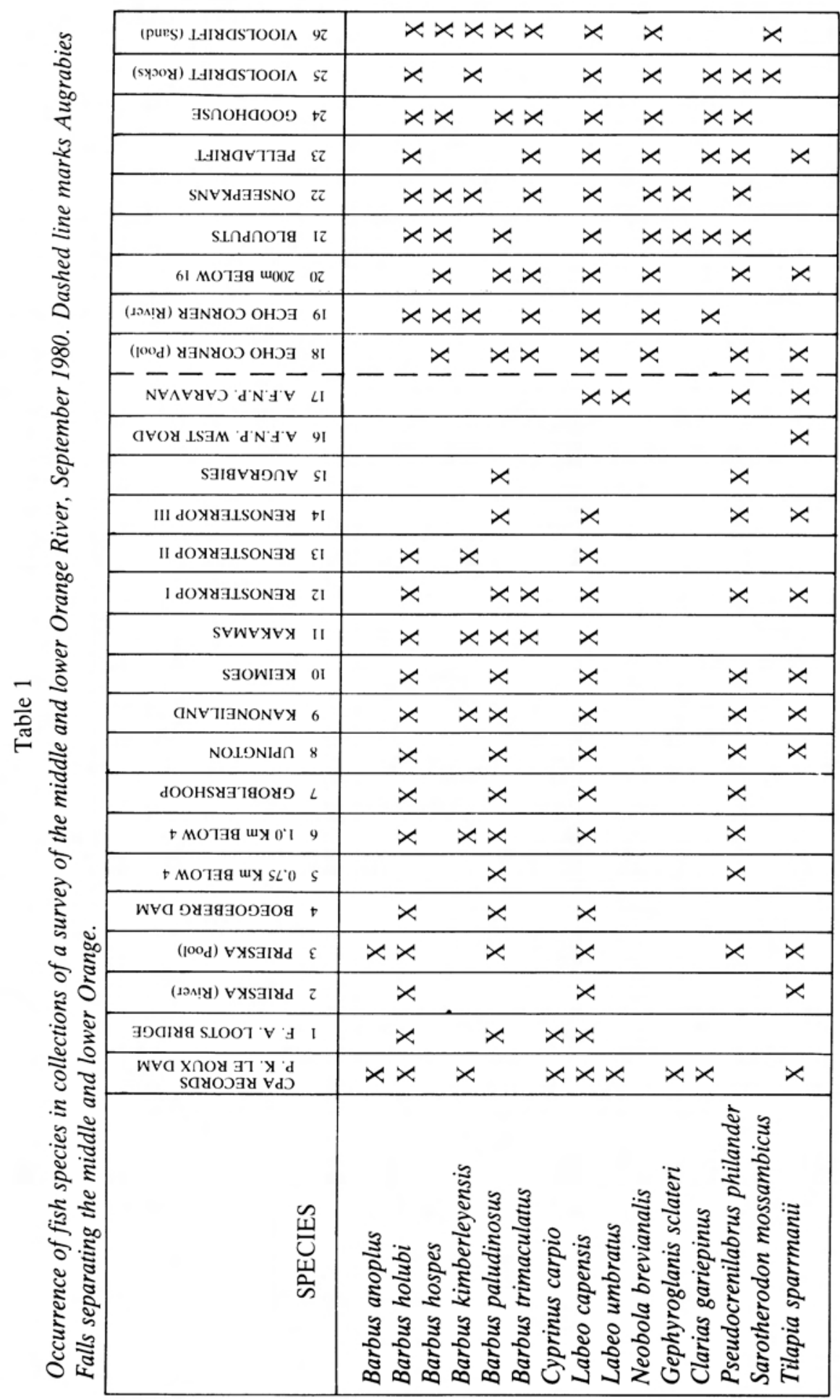


kimberleyensis is much less common than the smallmouth yellowfish (B. holubi). Two large specimens were caught in the gill nets at Echo Corner (AFNP), the largest was $59 \mathrm{~cm} \mathrm{SL}$ and weighed $4196 \mathrm{gm}$, the second specimen was $54 \mathrm{~cm} \mathrm{SL}$ and weighed $3064 \mathrm{gm}$. Smaller specimens were caught with a shocker in flowing channels at Onseepkans and in the rapids below Vioolsdrift weir. The smallest specimen identified was $75 \mathrm{~mm} \mathrm{SL}$. The indicated habitat preference of this species is flowing water below and in rapids, again corroborating Mulder's (1973a) findings. $B$. kimberleyensis is generally a silvery species, the larger adults having light orange fins.

Barbus paludinosus: This is an extremely widespread species in Africa and is known previously from both below and above the Augrabies Falls. Only a few specimens were collected. B. paludinosus was found at many sites, especially in quiet, weedy situations. There was no indication that this species had bred at the time of the survey.

Barbus trimaculatus: Another widespread African species known previously from above and below Augrabies Falls. Specimens were collected from quiet or slow flowing well vegetated marginal areas. It was more commonly netted in the lower Orange than in the middle Orange River. The three lateral spots, otherwise characteristic of the species, are not evident in living specimens from the lower Orange, although a round caudal spot is present. On preservation in formalin the three spots become evident in small individuals but only the caudal spot is clear in larger specimens from our collection. The largest individual measured $98 \mathrm{~mm} \mathrm{SL}$ and was taken from Station 19. The species does not appear to be abundant at any of the sites sampled during this survey.

Cyprinus carpio: Carp were introduced into the Cape in 1896 and are now widespread in the Orange-Vaal system (Jubb 1967). They represent an important part of the commercial fish catch from the Hendrik Verwoerd Dam (Visagie pers. comm.). The fact that this fish was only collected from the site above the confluence of the Orange-Vaal Rivers, indicated that the species is not finding the lower Orange and the lower reaches of middle Orange River to be a favourable habitat.

Labeo capensis: This is the most common large fish species in the Orange below and above the Falls. Mulder (1973b) reports that this species is also numerically - dominant in the Vaal River. Juvenile, subadult and adult specimens were collected in abundance at most stations and in a wide range of habitats. The range of habitats includes quiet, weedy backwaters, standing open waters, flowing open waters, sandy-rocky stretches and rocky rapids. The species, however, appears to prefer flowing rocky channels. The largest specimen examined was collected by gill net at Echo Corner ( $43 \mathrm{~cm} \mathrm{SL}, 1994 \mathrm{gm}$ ).

Labeo umbratus: A single specimen was collected within the AFNP from the braided channel behind the campsite. The species is evidently scarce in the vicinity of the Falls, and elsewhere in the stretch of river examined.

There are records of $L$. umbratus from Ais-Ais on the Fish River in South West Africa, collected by Dr. I. Gaigher in 1975. Our observations indicate that $L$. umbratus is not a particularly successful lotic species (at least in the face of competition from $L$. capensis) and seems to favour a lentic environment as reported by 
Marshall (1972) and Mulder (1973b).

Neobola brevianalis: Known previously as Engraulicypris brevianalis this small cyprinid is probably the most common and abundant species below Augrabies Falls. $N$. brevianalis is not found in the Orange River system above Augrabies Falls but is known from elsewhere further north in Africa including the Kunene and the upper Zambezi as well as the Limpopo and other east coast rivers as far south as the Pongola system. In the lower Orange it is abundant in open water habitats of the mainstream, in quiet backwater situations as well as in flowing channels and rapids. The compressed streamlined shape, large eyes and large terminal mouth suggest this is an active open water feeder. Preliminary examination of gut contents indicate that the species feeds on planktonic crustaceans. and terrestrial and aquatic insects (Pienaar 1978). At Vioolsdrift (Stations 25 \& 26) the gut contents of some individuals consisted largely of emerging, or semi-emerged, blackfly (Simuliidae) and the fish may be an important predator of this pest. Many specimens of $N$. brevianalis were in ripe breeding condition.

Gephyroglanis sclateri: Although reported without restriction from the Orange River system by Jubb \& Farquharson (1965), Jubb (1965) and Jubb (1967), no official records of the species were available from below Augrabies Falls. The two specimens from below the Falls were both electrofished from within rapids, and it is to be expected that many stretches of rapids within the AFNP and elsewhere have G. sclateri inhabitants. The species is not common even in its preferred habitat and this agrees with its general status in the system (P. le Roux in litt. 1976, Marshall 1972). A few specimens of this species have been collected in the P. K. le Roux impoundment gill net programme (S. Thorne pers. comm.) but they are seldom collected in the H. F. Verwoerd Dam.

Clarias gariepinus: The sharptooth catfish is distributed throughout the OrangeVaal system. Although large numbers were not collected by the party, there is no reason to suspect that the species is anything but common. Large specimens were collected in gill nets and with long lines from within the Augrabies Gorge (at Echo Corner). The largest of these (a female) measured $83,6 \mathrm{~cm} \mathrm{SL}$ and the mass was $5492 \mathrm{gm}$. Several juvenile specimens were collected from rocky habitats with the electric shocker. The species is reputed to attain extremely large sizes in the river within the Augrabies Gorge (R.A. Jubb pers. comm.). The skull of a large specimen collected below the Falls is displayed in the Park restaurant and measures $39 \mathrm{~cm}$ in length and $28 \mathrm{~cm}$ in width. Unfortunately, there are no published studies on head length/standard length ratios for the species and one can only approximate the standard length and weight of such a specimen. If taken as $25 \%$ of standard length (Jubb 1967), the standard length would be in the region of $150 \mathrm{~cm}$ and the mass, using comparative figures given by Bruton (1976) in the region of $25-30 \mathrm{~kg}$.

Pseudocrenilabrus philander: This small and rather attractive mouth-brooding cichlid was commonly encountered at most collection sites. These, surprisingly, are possibly the first official records for the species below Augrabies Falls. The habitat preference of the species was sheltered vegetated areas but the range of habitats in which it was found was noteworthy, rocky rapids, rocky shores, sandy open water, vegetated belts, in backwaters and flowing channels. At most sites females of the 
species were brooding young. Aquarium observations indicate that this is an extremely aggressive fish, and in view of its abundance in the middle and lower Orange, the species is probably an important component of the aquatic fauna in the river.

Sarotherodon mossambicus: This common east and south-east coastal river species was found only below the weir near Vioolsdrift. Apart from a sample collected by Dr. I. Gaigher at Ais-Ais on the Fish River, the Mozambique tilapia has not been recorded in the Orange River system below Augrabies Falls. Futhermore, it has not been recorded from the Orange River system, except from Hardap Dam where it was apparently introduced (I. Gaigher pers. comm.). It seems likely that it reached the present locality from this introduction site. Here it appears that the weir near Vioolsdrift is acting as an upstream barrier to the further dispersal of this species in the Orange.

Tilapia sparrmanii: The well known banded tilapia was widespread but not common in both the middle and lower Orange River. Whilst this is perhaps understandable in the Augrabies Gorge stretch where suitable habitats are scarce, it is surprising that larger numbers were not found in other sites where marginal and emergent vegetation are prevalent. In view of the abundance of the southern mouthbrooder Pseudocrenilabrus philander, one possible explanation is that there is an element of competitive displacement between the two species in the lower Orange River.

\section{Discussion}

There have been relatively few fish collecting or survey expeditions to the lower reaches of the Orange River. Barbus hospes was described from material collected by A. J. Hesse and C. W. Thorne of the South African Museum in November 1936. Mr. D. van Schoor undertook a gill net survey of various localities from above and below Augrabies Falls in 1971 and 1973 respectively. Dr. I. Gaigher made valuable collections of fishes from the lower reaches of the Fish River at Ais-Ais in South West Africa in 1975. It is clear from the available records that whereas the majority of species in the lower Orange have previously been recorded, very little about their abundance or details of distribution is known. The ubiquitous presence of Pseudocrenilabrus philander in the Augrabies Falls region and the lower Orange River is one rather surprising result of the survey. Jubb (1965) recorded that this species was found in the northern tributaries of the Orange, referring to the Molopo and Vaal systems. The two other cichlid species recorded are much less common and abundant in the localities collected by the party.

Several species, including Barbus pallidus, Oreodaimon quathlambae and the trouts Salmo gairdneri and S. trutta, are present in the Orange River system (Jubb 1967) but were not recorded during the survey. The trout species and $O$. quathlambae are cool mountain tributary forms and would not be expected in the lower reaches. Within the Orange-Vaal system Barbus pallidus is known from the Transvaal tributaries of the Vaal and again there was no real expectation of it being found in the lower Orange. Carp (Cyprinus carpio) is widespread in the eastern half of the Orange system and especially abundant in the large impoundments. An angler at Blouputs noted that he had not caught carp at that site before the 1974 
floods, but had since. So although they are known from the lower reaches, no specimens were collected. As in the case of Labeo umbratus the carp prefers lotic habitats which are not common in the lower Orange.

Barbus anoplus, and its closely related sister species B. motebensis (considered conspecific by Gaigher 1976) are widespread in South Africa. Their range includes the highveld reaches of the Limpopo (Gaigher 1973), the Orange-Vaal above their confluence, and the escarpment draining systems of the south-west, southern and south-eastern coast from the Olifants River in the west to the Limpopo in the east. One of the authors (J. A. C.) is making a field study of B. anoplus in the P. K. le Roux impoundment. On the basis of observations on this population no obvious physical reasons were detected why the species could not exist in the lower Orange River, let alone below Prieska. A possible factor may be that the temperature regimes are unsuitable for the species along this stretch. This suggestion is derived from correlation of the distribution of the species with the effective temperature (ET) distribution provided by Stuckenberg (1969). The species' distribution is confined more or less within the $16^{\circ} \mathrm{ET}$ isoline whereas the lower Orange region rises beyond this line. Any change to the present effective temperature regime, especially towards slightly warmer temperatures, as has occurred on past occasions (cited frequently in Werger 1978), would naturally reinforce the distribution pattern.

Skelton (1980) has implied that there may also be an historical factor involved in the distribution of B. anoplus and other Orange River species. It is interesting to record, for example, that the distribution in the Orange River system of Pseudocrenilabrus philander, Barbus paludinosus and Barbus trimaculatus (all widespread African species), includes the Vaal and its tributaries and the Orange below its confluence with the Vaal but not above the confluence (Albany Museum records). In discussing the biogeography of the redfin Barbus species and noting the strong faunal links between the Orange River and the Clanwilliam Olifants, Skelton (1980) suggested that the Orange River was formerly two independant systems: a) the upper Orange, draining south west to reach the sea via the Olifants River and, b) the lower Orange with an enlarged northern drainage, now remnant in the Molopo River and its tributaries. The distribution pattern of the mentioned species and the absence of $B$. anoplus to the west of Prieska, may all have been a consequence of the historical drainage lines. It remains, however, to explain why the species should not have subsequently dispersed beyond such possible historical ranges in this system. Certainly temperature regimes may be one reason, operating at upper tolerance levels for the more temperate $B$. anoplus and at lower tolerance levels for the tropical B. paludinosus, B. trimaculatus and $P$. philander.

A second remarkable point of correlation to note, at least in regard to the distribution of $B$. anoplus, is that the species is confined to the mainbody of the Karoo geological System in southern Africa. In many places this correlation is accurate in the extreme e.g. it is at Prieska that the Dwyka series (Karoo System) (east) meets the Transvaal System (west). Secondly B. anoplus is the only primary freshwater fish in the rivers of the Transkei from the Great Kei River in the south to the Umtamvuna River in the north, a region known as the Transkei gap (Bowmaker, Jackson \& Jubb 1978; Cambray 1978). The Karoo System reaches the coast across 
this region. Thirdly in the Clanwilliam Olifants River system of the western Cape $B$. anoplus is not found where Cape System geology prevails. In a tributary, the Brandkraal River, however, a healthy population is known from the zone of interface between the Cape and the Karoo Systems. As Karoo System rocks impart distinctive characteristics to the groundwater (Bond 1946) these observations suggest that water quality may be a limiting factor in the distribution of $B$. anoplus in the Orange River system.

The Orange-Vaal system is clearly a highly regulated one by virtue of the number of large impoundments and weirs along its course (Fig. 1) and the extensive agricultural and industrial use of its waters. Undoubtedly this regulation and extraction has induced ecological changes especially along the middle and lower courses covered by the present survey. Unfortunately, as pointed out by Davies (1979), there has been almost no monitoring of these changes and our comments are aimed at the situation at the present time. Noble \& Hemens (1978) have considered both the beneficial and detrimental aspects of the effects of dams and weirs on river ecology.

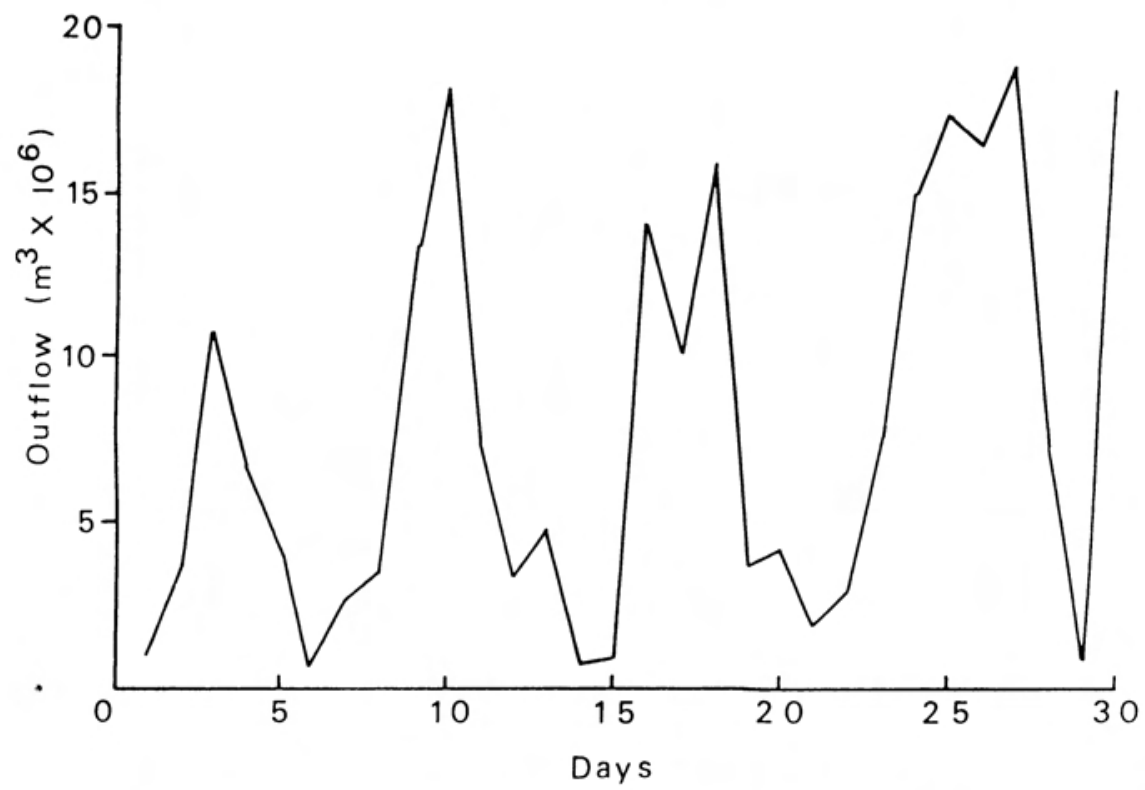

Fig. 3. Daily outflow from P. K. le Roux Dam for the month of September 1980. (Source Dept. Water Affairs).

A daily fluctuation in the water volume is readily observed along the middle and lower Orange (Sept, 1980). This fluctuation is largely governed by the controlled outflow of the P.K. le Roux Dam, the extent of which can be gathered from Fig. 3, giving the outflow for September 1980. One of the major effects of such an erratic outflow is a destabilization of the shallow marginal areas of the river. These are particularly important areas in the ecology of many fish species especially in the role 
of defensive cover, spawning, nursery and feeding sites. There are indications that similar outflow regimes from the H. F. Verwoerd Dam are influencing the breeding patterns of Barbus holubi and Labeo capensis in the riverine sections of the P. K. le Roux Dam (Cambray \& Hahndiek 1980; T. Tomasson, pers. comm.).

Another change to note is that whereas there is now an erratic daily flow in the river the annual flow is more regular and less erratic than the natural flow in the past. A more regular annual flow acts to deminish the isolation of cut-off pools, cushions floods (except possibly the larger ones) and reduces seasonal fluctuations in temperature, all of which are probably important factors in the ecology of fishes and other aquatic organisms. De Kock, Pretorius \& van Eeden (1974) found that the Boegoeberg Dam played an important role in establishing and maintaining suitable habitats in the middle Orange River for freshwater snail species which depend on permanent habitats.

There is no doubt that the effect of impoundment draw down throughout the system is poorly understood and urgently requires research attention.

One of the objectives of the survey was to evaluate the conservation status of fish species in the middle and lower Orange River. In particular our attention was focused on Barbus hospes which was listed in the South African Red Data Fishes book by Skelton (1977). The species occurred at most sites visited in the lower Orange, but it was not present in large numbers. Although no standardization or realistic comparison is implied it may be noted that one of the authors (PHS) collected a larger sample with less effort by seining at Echo Corner (Stations 18 and 19 ) in October 1973 than was collected with the more intensive efforts of the party in September 1980. Further comment is, however, speculative until the biology and ecology of the species is more accurately studied.

The manipulation and extensive extraction of water for industrial, domestic and agricultural purposes suggests that there is probably less water in the lower Orange River than in the past. The open water habitat preferred by $B$. hospes could therefore have been adversely effected (at least in terms of volume, current and suspension load) and the species may be declining in response to such changes.

In general other small Barbus species and Tilapia sparrmanii were encountered in low numbers during the survey. These species favour shallow well vegetated marginal areas of the river. It is possible that their low numbers are a result of the induced daily instability of these areas as exposed above.

Part of a programme to control blackfly (Simuliidae) involves suspension of outflow from the large dams. This causes sustained drops in water level habitats (shallow rocks in running stretches). The ecological effects of this control programme extend, in all probability, to other organisms and habitats. In addition, with the planning of new dams, the increased mining activity in the north-west Cape and the anticipated rapid development of the Upington region it is likely that such ecological changes on the middle and lower Orange River will escalate further. The repercussions of these changes on indigenous fauna may well be greater than in other comparable situations because there is little independant tributary inflow to the Orange River along these reaches. The opportunity for sanctuary situations to exist are therefore low. For this reason alone the ecology of the lower and middle 
Orange River should receive sympathetic priority for urgent study by involved parties.

\section{Acknowledgements}

Permission to undertake this work was granted by the Directors of the Albany Museum, Grahamstown, and the Cape Department of Nature and Environmental Conservation. The survey within the Augrabies Falls National Park was sanctioned by the National Parks Board of Trustees. We are grateful for this permission and for the friendly co-operation of the Park Warden Mr. A. W. A. Duvenhage. The research was funded by the Cape Department of Nature and Environmental Conservation. Assistance in the field was given by Messrs. S. Harmse and S. Cramer (Cape Dept. of Nature and Environmental Conservation), Mr. G. Butler, Miss Alison Wilson, Mr. C. Nonqane, Mr. \& Mrs. S. Hall, all of the Albany Museum, and Dr. W. Branch (Port Elizabeth Museum). Dr. M. N. Bruton kindly read and commented on the manuscript.

\section{REFERENCES}

BARNARD, K. H. 1943. Revision of the Indigenous freshwater fishes of the SW Cape region. Ann.S.Afr.Mus. 36: 101-262

BOND, G. W. 1946. A geochemical survey of the underground water supplies of the Union of South Africa. Mem.geol. Surv.Un.S.Afr. 41.

BOWMAKER, A. P., P. B. N. JACKSON and R. A. JUBB. 1978. Freshwater fishes. In M. J. A. WERGER (Ed.) Biogeography and Ecology of southern Africa. The Hague: Junk.

BRUTON, M. N. 1976. On the size reached by Clarias gariepinus. J. Limnol.Soc.stn.Afr. 2:57-58.

BURCHELL, W. J. 1822. Travels in the Interior of Southern Africa. 1. London: Longman, Hurst, Rees, Orme and Brown.

CAMBRAY, J. A. 1978. A contribution to the character phylogeny of the Anabantidae with particular reference to the respiratory organs of Sandelia bainsii. B.Sc. (Hons) Project, Rhodes Univ. Grahamstown, RSA. (unpublished).

CAMBRAY, J. A., S. HAHNDIEK and Q. HAHNDIEK. 1978. The juvenile fish population in the marginal areas of the Hendrik Verwoerd Dam. $J$. Limnol.Soc.sth.Afr. 4: 21-30.

CAMBRAY, J. A. and Q. HAHNDIEK. 1980. The juvenile and minnow populations in the marginal areas of the P. K. le Roux Impoundment, Orange River, South Africa. C. P. A. Dept. Nature and Environmental Conservation Research Report 1980: 17-54. 
DAVIES, B. R. 1979. Stream regulation in Africa: a review. In J. V. Ward and J. A. Stanford (Eds) The Ecology of Regulated Streams. New York: Plenum Press.

DE KOCK, K.N., S. J. PRETORIUS and J.A. VAN EEDEN. 1974. Voorlopige kommentaar aangaande die voorkoms van die varswaterslakke in die Oranjerivier 1. die opvanggebied: 186-202. In E. M. VAN ZINDEREN BAKKER (Ed.) The Orange River. Institute for Environmental Sciences, U.O.F.S.

GAIGHER, I. G. 1973. The habitat preferences of fishes from the Limpopo River system, Transvaal and Mocambique. Koedoe 16: 103-116.

GAIGHER, I. G. 1976. Geographical variation and synonymy of the minnows Barbus motebensis Steindachner (1894) and B. anoplus M. Weber (1897). C. P. A. Dept. Nature and Environmental Conservation Research Report 1976: 171-178.

JUBB, R. A. 1965. Freshwater fishes of the Cape Province. Ann. Cape. Prov. Mus. 4:1-72.

JUBB, R. A. 1967. Freshwater fishes of Southern Africa. Cape Town: A. A. Balkema.

JUBB, R. A. and F. L. FARQUHARSON. 1965. Freshwater fishes of the Orange River Drainage Basin. S.Afr.J.Sci. 61:118-125.

MARSHALL, R. D. 1972. A preliminary fish survey of the Caledon River System. Civ.Engr.S.Afr. 14:96-97.

MULDER, P. F. S. 1973a. Aspects on the ecology of Barbus kimberleyensis and Barbus holubi in the Vaal River. Zool.afr. 8:1-14.

MULDER P. F. S. 1973b. Aspects on the ecology of Labeo capensis and Labeo umbratus in the Vaal River. Zool.afr. 8:15-25.

NOBLE, R. G. and J. HEMENS. 1978. Inland water ecosystems in South Africa - a review of research needs. South African National Scientific Programmes Report 40.

PIENAAR, U. de V. 1978. The freshwater fishes of the Kruger National Park. National Parks Board of Trustees of the Republic of South Africa.

SKELTON, P. H. 1977. South African Red Data Book - Fishes. South African National Scientific Programmes Report 14: 1-39.

SKELTON, P. H. 1980. Systematics and biogeography of the redfin Barbus species (Pisces, Cyprinidae) from southern Africa. Ph.D. thesis. Rhodes Univ. Grahamstown, RSA. (unpublished).

SMITH, A. 1849 (=1841). Illustrations of the Zoology of South Africa. London: Smith, Elder and Co.

STUCKENBERG, B. R. 1969. Effective temperature as an ecological factor in southern Africa. Zool.afr. 4:145-197.

VAN SCHOOR, D. J. 1972. Relative population densities and breeding habits of fish in the upper Orange River. Civ. Engr. S.Afr. 14:94-96.

WERGER, M. J. A. (Ed.) 1978. Biogeography and Ecology of southern Africa. The Hague: Junk. 